\title{
Stakeholder Management: Formulating a Primer for Practitioners
}

\section{Orlando E. Contreras-Pacheco, Juan Camilo Lesmez Peralta}

School of Industrial Engineering and Business, Universidad Industrial de Santander, Colombia.

\begin{abstract}
Stakeholder management is the act of balancing the competing preferences or claims of company stakeholders for the sake of competing, collaborating, and succeeding. The present manuscript structures a primer, in the shape of a pedagogical proposal about the topic of stakeholder management. For this purpose, it introduces the reader to terms and concepts that are necessary to understand stakeholder management as an alternative way to manage organizations in both utilitarian and ethical manner. It also offers sufficient grounding in the field that enables the reader to interpret the insights of stakeholder management as a dynamic and cross-functional concept. The present work addresses practitioners, students, scholars and instructors in any topic of the business administration domain, which desires to validate alternatives to the traditional view of a shareholder-oriented way to manage.
\end{abstract}

Keywords: Stakeholders; Stakeholder management; Executive education; Value creation. 


\section{Introduction}

According to scholars like Argandoña (2011), both the theory and practice of corporate social responsibility (CSR) fluctuates between two extremes. On the one hand, a linear approach that reduces the businesses' responsibility to the procurement of the highest possible profit for its shareholders (e.g., Jensen, 2000). On the other hand, a direct approach that extends the businesses' responsibility to include a wide range of actors with an interest or "stake" in the business, called the stakeholders (e.g., Donaldson \& Preston, 1995; Freeman, 1984). It is evident that for both cases, the ultimate goal of the theory of CSR is the welfare of society. However, for the second approach the concept of "value" is subject to further explanations.

By acknowledging the duality mentioned above, this manuscript attempts to outline a pedagogical proposal for a module in stakeholder management (SM). This proposal is oriented singularly to enhance either an executive diploma program or a focused Masters program. For this purpose, this manuscript introduces the reader to terms and concepts that are necessary to understand SM and their application to modern organizations. Furthermore, it suggests a module structure that helps instructors to address the topic of SM as a fundamental part of management-oriented topics like strategy, marketing, supply chain, and HRM.

In the first instance, it is crucial to present the objective and learning outcomes projected for an archetypal SM module. Worth to mention, for a course in SM within executive education programs, students are expected to have followed undergraduate (or graduate) courses in management or organizational behavior, marketing, and business strategy.

\subsection{SM Module Objective}

In essence, the purpose of a module in SM is to provide prospective students with a conceptual framework for understanding how an organization's management can identify its stakeholders and manage its relationships with them. In the long run, this module will help students to recognize how to optimize the triple bottom line - economic, social, and environmental sustainability - through a successful CSR strategy.

\subsection{SM Module Intended Learning Outcomes}

By the end of a module of SM, students will be able to: 1) Critically evaluate the main theoretical and conceptual approaches to SM; 2) Evaluate how a company identifies its stakeholders and assess its relationships with them; 3) Consider the strategic opportunities provided by SM within the different areas of the business management body of knowledge; and 4) Apply the concepts of SM to formulate recommendations at the managerial level. 


\section{Conceptual Framework}

Sustainable Development is defined as the enhancement of existing human living standards without compromising those of future generations (UN, 1987). A Stake is conceived as any interest or share in an undertaking. A stake can also be a claim or demand (Buchholtz \& Carroll, 2012). "The idea of a stake can range from simply an interest in an undertaking at one extreme to a legal claim of ownership at the other" (Buchholtz \& Carroll, 2012; p.63). For its part, the concept of Stakeholder was originally defined as any group that the firm relies upon: "those groups without whose support, the organization would fail to exist" (Ackoff, 1974). However, in a widely accepted definition, stakeholders were conceived by Freeman (1984) as "any group or individual who can affect or is affected by the achievement of a business' objectives" (p.46). Converserly, Legitimacy is a generalized perception or assumption that the actions of an entity are desirable, proper, or appropriate within some socially constructed system of norms, values, beliefs, and definitions (Suchman, 1995). Finally, Value is broadly defined as anything that has the potential to be of worth to Stakeholders. The term "utility" will be understood to reflect the value a stakeholder receives that actually has merit in the eyes of the stakeholder (Harrison \& Wicks, 2013).

\section{Justification, Theory, and Foundations}

The stakeholder theory (ST) is essentially about organizational management and ethics (Phillips, Freeman, \& Wicks, 2005). From that lens, ST is also about how business works at its best, and how it could work. It is descriptive, prescriptive, and instrumental at the same time (Donaldson \& Preston, 1995), and is about value creation and trade and how to manage a business effectively. "Effective" can be seen as "create as much value as possible." Furthermore, their body of knowledge suggests that if we adopt as a unit of analysis the relationship between a business and its stakeholders, then we have a better chance to deal with other problems. For instance, the one of value creation and trade, or one of the ethics of capitalism; and iii) the one of managerial mindset (Freeman, Harrison, \& Wicks, 2007). Finally, ST attempts to articulate a central question in a systematic way: which groups are stakeholders deserving or requiring management attention, and which are not? In other words: who is a stakeholder (stakeholder identification), and what is at stake? (Mitchell, Agle, \& Wood, 1997).

Since its introduction in 1984, this theory has been an essential cornerstone in the study of the concept of management at every level (Freeman, 1984). It arrived to counterbalance the traditional view of financial value maximization, or what Jensen (2000) labelled "the manager's oath." Some scholars claim that the ST has been proposed as an alternative to shareholder theory. This idea means that the dynamics of both value creation and value 
appropriation experimented profound changes so as they are conceived and applied. Consequently, by this moment, stakeholders ought to be taken into account for these kinds of "strategic" assessments (Coff, 2010). Understanding this phenomenon in complex contexts represents a research opportunity that could lead us to exciting contributions.

Complementarily, according to Freeman (2010), the stakeholder approach (SA) is an idea about synergism, and about how a business works. This approach suggests that for any business to be successful, it has to create value for costumers, suppliers, employers, communities, and financiers (mainly shareholders and banks). It says that a manager can not look at any one of those stakes in isolation. Their interests have to go together. And the job of a manager is to figure out how those interests go in the same direction.

Therefore, the SA is the idea that each one of these groups is important to the success of a business; and figuring out how their interests can go in the same direction is what the managerial task is all about. The SA indicates that if a manager just focuses on financiers, the manager misses what makes capitalism tick, which is that all stakeholders can together create something that no one can create alone.

\subsection{Stakeholder Identification}

In today's hypercompetitive, global business environment, any individuals and groups are business stakeholders. However, from the business point of view, specific individuals and groups have more legitimacy in the eyes of the management; that is, they have a legitimate, direct interest in, or claim on the operations of the firm. And while the most obvious of these groups are shareholders, employees, and customers, from a highly pluralistic society, stakeholders include not only these groups but other groups as well. These other groups include the community, competitors, suppliers, trade associations, the media, and society, or the public at large (Buchholtz \& Carroll, 2012).

In a first instance, Freeman (1984) stated that stakeholders were divided into two types: internal (owners, customers, employees, and suppliers) and external (governments, competitors, consumer advocates, environmentalists, special interest groups, citizens, and the media). However, further developments took place in this matter, and new typologies arose, especially in terms of their nature and interests. Fehr and Falk (2002) built on this and suggested that stakeholders can be categorized into two main types: self-regarding and reciprocal. The former type concerns a stakeholder who only cares about a personal "tangible" retribution, while the latter type uses to value fairness in a business relationship.

Nevertheless, an important question that has been addressed is to which groups do managers pay attention? Mitchell et al. (1997) developed a model of stakeholder identification and salience based on stakeholders possessing one or more of the attributes of power, legitimacy, and urgency. Later, Magness (2008) confirmed that the three attributes 
do lead to salience. Thus, we might anticipate that firms would pay the most attention to those legitimate stakeholder groups who have power and urgency. In practice, this might mean that firms with problems over employee retention would attend to employee issues, and those in consumer markets would have regard to matters that affect reputation. Stakeholder groups may also become more or less urgent, so environmental groups and issues became more urgent to oil firms following the Exxon Valdez oil spill example (Patten, 1992).

\subsection{Managing Stakeholders}

The nature of ST is managerial in the broad sense of that term. It does not merely describe existing situations or predict cause-effect relationships; it also recommends attitudes, structures, and practices that, taken together, constitute SM. This requires, as its key attribute, simultaneous attention to the legitimate interests of all appropriate stakeholders, both in the establishment of organizational structures and general policies and in case-bycase decision making (Donaldson \& Preston, 1995).

The fundamental idea of SM is that business can be understood as a set of relationships among groups, which have a stake in the activities that make up the business. Business is about how costumers, suppliers, employees, financiers (shareholders, bondholders, and banks, among others), communities, and managers interact and create value. To understand a business is to know how these relationships work. And the executive's or entrepreneur's job is to manage and shape these relationships (Freeman, 2010).

In this vein, SM is defined as the action of balancing the competing preferences or claims of the stakeholders (Reynolds, Schultz, \& Hekman, 2006). Also, more practically and accurately, it can be conceived as the management of expectations of parties involved designed to fulfill the various interests at stake (Manetti \& Toccafondi, 2012). Consequently, the height of the SM process is known as stakeholder engagement, which is understood as a process with mutual benefits for companies and stakeholders that draws on a cooperative scheme called a "mutually beneficial and just scheme of cooperation."

\section{Classroom Activity}

Cases based on real crisis incidents can work as an exercise in order to collectively assess what the key stakeholders are in a critical situation. At the same time, they can work for teaching how to desig a stakeholder communication plan in order to deal properly with a crisis. The activity described by Contreras-Pacheco, Talero-Sarmiento, \& EscobarRodríguez (2020) is a vivid example of the latter. The book written by Coombs (2019) is full of such examples, together with their corresponding instructor notes and feedbacks. 


\subsection{Understanding the Stakeholder's View of the Firm}

Lately, from the management perspective, it has widely argued that "for sustainable development to become a reality, the SA offers the best opportunity" (Buchholtz \& Carroll, 2012; p.63). In that sense, it has also been argued that SM is an outcome of the Value Creation \& Appropriation Approach (Brandenburger \& Stuart, 1996). See figure 1.

The ST for its part, is introduced as an evolution of a purely rational approach based on the self-interesting of actors in an economic relation. It primarily claims that organizations should be managed in the interest of all their constituents, not only in the interest of shareholders (Laplume, Sonpar, \& Litz, 2008). Furthermore, true sustained value creation is achieved when a company has a purpose and when decisions are made on the basis of a set of authentic values (Harrison \& Wicks, 2013). In other words, adequate distribution of the created value into different stakeholders becomes a long-term source of sustained value creation. Later, this became the primary input of a powerful and practical idea, which Porter \& Kramer (2011) labeled as "Shared Value Creation."

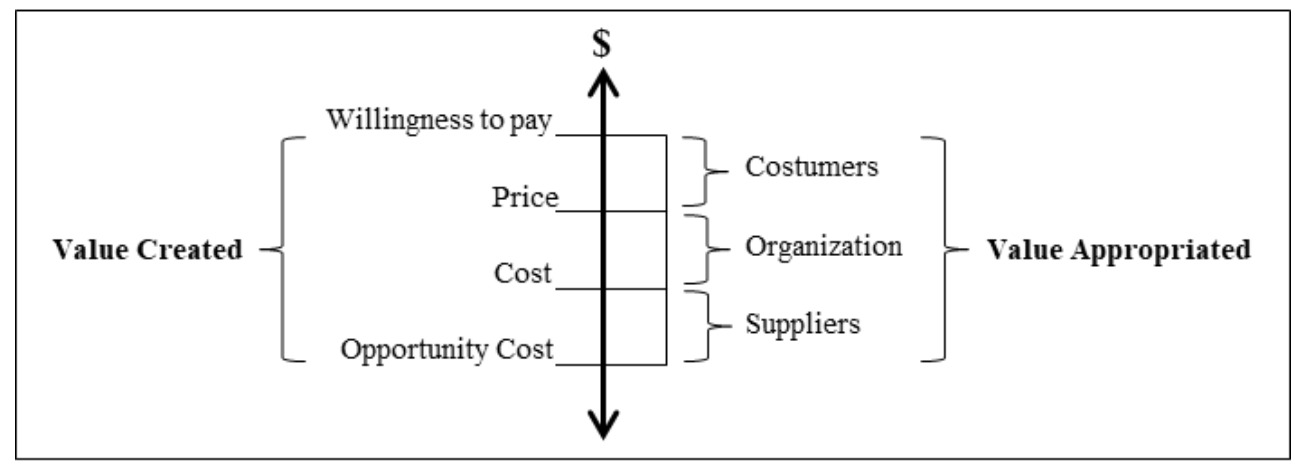

Figure 1. Value Creation - Appropriation Model (Brandenburger \& Stuart, 1996)

However, one of the keys of this last idea is the way to obtain the "adequacy" in the distribution of value between participant stakeholders. Assessing this process can be confusing but necessary. In this sense, different scenarios appear to diagnose reality in this matter. One valid approach is the one named "Stakeholder value appropriation trade-offs" (Stakeholder VA Taxonomy), which was recently proposed by García-Castro \& Aguilera (2015). They developed a useful categorization model that addresses the relationship between the value appropriated by stakeholders and the total value created in a period by a conventional stakeholder interaction.

García-Castro and Aguilera's (2015) proposal explains, in 7 generic scenarios, how the value created in a specific period is distributed into two stakeholders who are part of a conventional stakeholder relationship. First, the value creation of this interaction can be identified as one of three possibilities: 1) positive-sum game (there is value creation); 2) 
negative-sum game (there is value destruction); and 3) zero-sum game (there is neither creation or destruction of value). At the same time, it is needed to identify the value appropriation "equilibrium" of each stakeholder during the interaction. First, it can be a balanced appropriation, when the proportion of either creation or destruction is the same for both stakeholders; second, it is possible to find a scenario where value-creation (or valuedestruction) of one stakeholder implies no value-modification for the other stakeholder; this means neutrality. Finally, it is possible to note that under an unbalanced output, one stakeholder can capture value at the expense of the other. See Figure 2.

\begin{tabular}{|c|c|c|c|c|}
\hline & & Balanced & Neutal & Unbalanced \\
\hline \multirow{3}{*}{ 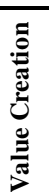 } & Positive & 1. Sharing value & $\begin{array}{l}\text { 2. Stakeholder neutrality } \\
\text { (gains absorption) }\end{array}$ & $\begin{array}{c}\text { 3. Over-appropiation of } \\
\text { value }\end{array}$ \\
\hline & Negative & 4. Sharing losses & $\begin{array}{c}\text { 5. Stakeholder neutrality } \\
\text { (loss absorption) }\end{array}$ & $\begin{array}{l}\text { 6. Over-appropiation of } \\
\text { remains }\end{array}$ \\
\hline & Zero & \multicolumn{3}{|c|}{ 7. Zero-sum } \\
\hline
\end{tabular}

Figure 2. Stakeholder VA Taxonomy (García-Castro, Aguilera, 2015)

\section{Questions for testing and for future developing}

How important are for SM to have a truthful purpose and values?; What is the relationship between stakeholder power and stakeholder interest?; How should a manager communicate with the company's stakeholders?; What is the relationship between SM and firm financial performance?; What is the relationship between SM and corporate social performance?; What are other organizational outcomes affected by SM?

\section{References}

Ackoff, R. L. (1974). The Social Responsibility of Operational Research. Operational Research Quarterly, 25(3), 361-371.

Argandoña, A. (2011). Stakeholder Theory and Value Creation. In XIX Congreso EBEN España (pp. 1-14). Barcelona.

Brandenburger, A. M., \& Stuart, H. W. J. (1996). Value-Based Business Strategy. Journal of Economics \& Management Strategy, 5(1), 5-24. https://doi.org/10.1111/j.14309134.1996.00005.x

Buchholtz, A. K., \& Carroll, A. B. (2012). Business and Society: Ethics and Stakeholder Management. Canada: Cengage Learning.

Clarkson, M. B. E. (1995). A Stakeholder Framework for Analyzing and Evaluating Corporate Social Performance. Academy of Management Review, 20(1), 92-117.

Coff, R. W. (2010). The coevolution of rent appropriation and capability development. Strategic Management Journal, 31(7), 711-733. https://doi.org/10.1002/smj.844 
Contreras-Pacheco, O. E., Talero-Sarmiento, L. H., \& Escobar-Rodríguez, L. (2020). Sostenibilidad, stakeholders y crisis de empresa: un análisis estructurado de percepciones. Suma de Negocios, 11(24), In press.

Coombs, W. T. (2019). Ongoing Crisis Communication: Planning, Managing and Responding (Fifth Ed.). Thousand Oaks, CA: SAGE Publications Ltd.

Donaldson, T., \& Preston, L. E. (1995). The Stakeholder Theory of the Corporation: Concepts, Evidence, and Implications. Academy of Management Review, 20(1), 65-91.

Flammer, C. (2015). Does Corporate Social Responsibility Lead to Superior Financial Performance? A Regression Discontinuity Approach. Management Science, 61(11), 2549-2568. https://doi.org/10.1017/CBO9781107415324.004

Freeman, R.E., Harrison, J. S., \& Wicks, A. C. (2007). Managing for Stakeholders: Survival, Reputation and Success. Boston, Massachusetts: YALE University Press.

Freeman, R Edward. (1984). Strategic Management: A Stakeholder Approach. Boston: Pitman Series in Business and Public Policy. Retrieved from http://www.mendeley.com/research/strategic-management-a-stakeholder-approach-2/

Freeman, R Edward. (2010). Managing for Stakeholders: Trade-offs or Value Creation. Journal of Business Ethics, 96, 7-9. https://doi.org/10.1007/s

Friedman, M. (1970). The Social Responsibility of Business is to Increase its Profits. The New York Times, pp. 122-124.

Frooman, J. (1999). Strategies Influence. The Academy of Management Review, 24(2), 191205.

García-Castro, R., \& Aguilera, R. V. (2015). Incremental Value Creation and Appropriation in a World with Multiple Stakeholders. Strategic Management Journal, 36, 137-147. https://doi.org/10.1002/smj.2241

Godfrey, P. C. (2005). The Relationship between Corporate Philanthropy and Shareholder Wealth: A Risk Management Perspective. Academy of Management Review, 30(4), 777-798.

Harrison, J. S., \& Wicks, A. C. (2013). Stakeholder Theory, Value, and Firm Performance. Business Ethics Quarterly, 23(1), 97-124. https://doi.org/10.5840/beq20132314

Jensen, M. (2000). Value maximization and the corporate objective function. In Breaking the code of change (pp. 37-57).

Laplume, A. O., Sonpar, K., \& Litz, R. A. (2008). Stakeholder Theory: Reviewing a Theory That Moves Us. Journal of Management, 34(6), 1152-1189. https://doi.org/10.1177/0149206308324322

Magness, V. (2008). Who are the stakeholders now? An empirical examination of the Mitchell, Agle, and Wood theory of stakeholder salience. Journal of Business Ethics, 83(2), 177-192. https://doi.org/10.1007/s10551-007-9610-2

Manetti, G., \& Toccafondi, S. (2012). The Role of Stakeholders in Sustainability Reporting Assurance. Journal of Business Ethics, 107, 363-377. https://doi.org/10.1007/s10551011-1044-1 
Mitchell, R. K., Agle, B. R., \& Wood, D. J. (1997). Toward a Theory of Stakeholder Identification and Salience: Defining the Principle of Who and What Really Counts. Academy of Management Review, 22(4), 853-886. https://doi.org/10.5465/AMR.1997.9711022105

Patten, D. M. (1992). Intra-Industry Environmental Disclosures in Response to the Alaskan Oil Spill: A Note on Legitimacy Theory. Accounting, Organizations and Society, 17(5), 471-475.

Phillips, R. A., Freeman, R. E., \& Wicks, A. C. (2005). What Stakeholder Theory Is Not. Business Ethics Quarterly, 13(4), 479-502. https://doi.org/10.2307/3857968

Porter, M., \& Kramer, M. (2011). Creating Shared Value. Harvard Business Review, 89(1/2), 62-77. https://doi.org/10.1108/09600039410055963

Reynolds, S. J., Schultz, F. C., \& Hekman, D. R. (2006). Stakeholder Theory and Managerial Decision-Making: Constraints and Implications of Balancing Stakeholder Interests. Journal of Business Ethics, 64, 285-301. https://doi.org/10.1007/s10551005-5493-2

Suchman, M. C. (1995). Managing Legitimacy: Strategic and Institutional Approaches. Academy of Management Review, 20(3), 571-610.

Sundaram, A. K., \& Inkpen, A. C. (2004). The Corporate Objective Revisited. Organization Science, 15(3), 350-363. https://doi.org/10.1287/orsc.1040.0068

UN. (1987). World Commission on Environment and Development, Report of the World Commission on Environment and Development: Our Common Future. 